\title{
RANCANG BANGUN SISTEM PAKAR PENENTUAN PEYAKIT DOMBA MENGGUNAKAN METODE CERTAINTY FACTOR
}

\author{
Dinar Purwa Asih $^{1}$, Indra Dharma Wijaya ${ }^{2}$, Budi Harijanto ${ }^{3}$ \\ ${ }^{1}$ Jurusan Teknologi Informasi, Fakultas Teknik Informatika, Politeknik Negeri Malang \\ 11.1narpurwa@gmail.com, ${ }^{2}$ indra.dharma@gmail.com, ${ }^{3}$ budi.hijet@gmail.com
}

\begin{abstract}
Abstrak
Domba merupakan hewan ternak yang banyak memberikan manfaat seperti daging, susu, dan bulu. Domba yang sehat akan menghasilkan daging dan susu yang berkualitas bagus. Salah satu faktor yang mengakibatkan ternak domba mudah terserang penyakit adalah kualitas pakan dan virus pada keadaan lingkungan. Perawatannya membutuhkan biaya lebih sehingga diperlukan suatu cara untuk mengetahui penyakit dan solusinya agar dapat melakukan tindakan-tindakan yang diperlukan. Terbatasnya jumlah pakar di daerah pedesaan serta kurangnya penyebaran pengetahuan, menyebabkan diperlukan system pakar untuk diagnosis penyakit domba. Untuk mengatasinya dibuat sistem kepakaran yang dapat diakses oleh peternak domba yang bersifat online. Sistem pakar harus mampu bekerja dalam ketidakpastian, sehingga ditambahkan metode Certainty Factor (CF) untuk mengatasi permasalahan tersebut. Sistem dikembangkan dengan menganalisis gejala-gejala penyakit yang diinputkan kemudian diolah menggunakan kaidah produksi dan perhitungan $\mathrm{CF}$. Ketepatan output sistem dibuktikan dari hasil validitas sistem dengan pakar. Uji coba sistem pada 7 kasus dengan pakar menghasilkan tingkat akurasi sebesar $85,71 \%$.
\end{abstract}

Kata Kunci : sistem pakar, penyakit domba, certainty factor $(\mathrm{CF})$

\section{Pendahuluan}

Domba merupakan hewan ternak yang banyak memberikan manfaat seperti daging, susu, dan bulu. Domba yang sehat akan menghasilkan daging dan susu yang berkualitas bagus. Adapun jenis penyakit pada ternak domba antara lain:radang pusar, cacar mulut, titani, radang limpa, mulut \& kuku, ngorok, perut kembung, kudis, dermatitis, kelenjar susu. Salah satu faktor yang mengakibatkan ternak domba mudah terserang penyakit adalah kualitas pakan dan virus pada keadaan lingkungan. Pengembangan peternakan domba mempunyai prospek yang baik karena di samping untuk memenuhi kebutuhan daging dan susu di dalam negeri. Untuk mendukung pengembangan domba di masa yang akan datang, jumlah dan mutu bibit merupakan faktor produksi yang sangat strategis dan menentukan keberhasilan program pembangunan peternakan. Pembibitan domba saat ini masih berbasis pada peternakan rakyat yang berciri skala usaha kecil, manajemen sederhana, pemanfaatan teknologi seadanya, lokasi yang kurang mendukung, dan berbagai penyakit.

Dengan semakin majunya teknologi dan informasi saat ini, maka membawa pengaruh dalam kemajuan perkembangan komputer khususnya pada perkembangan perangkat lunak, termasuk salah satunya adalah sistem pakar yang merupakan cabang dari kecerdasan buatan. Sistem pakar merupakan program komputer yang dirancang untuk memodelkan kemampuan menyelesaikan masalah seperti layaknya seorang pakar berdasarkan pengetahuan dan pengalamannya. Metode yang digunakan sistem ini adalah certainty factorsebagai mesin inferensinya. Sistem pakar harus mampu bekerja dalam ketidakpastian. Definisi menurut David McAllister (Alatas dan Maulidia G., 2009), Metode certainty factoradalahsuatu metode untuk membuktikan apakah suatu fakta itu pasti ataukah tidak pasti yang berbentuk metric yang biasanya digunakan dalam sistem pakar. Metode ini sangat cocok untuk sistem pakar yang mendiagnosis sesuatu yang belum pasti. Sistem pakar yang akan dibangun dalam penelitian ini menggunakan Certainty Factor untuk penanganan masalah ketidakpastian.Pada penelitian ini pakar merupakan dokter hewan. Dokter hewan akan mendiagnosis penyakit yang diderita berdasarkan gejala yang muncul pada domba.

Berawal dari permasalahan tersebut, penilitian domba ini dibuat pada daerah Wates Kab, Kediri. Dengan sistem ini, diharapkan peternak domba dapat lebih mengetahui gejala-gejala penyakit pada domba mereka, dan memudahkan memelihara domba agar tidak terjangkit penyakit, sedangkan bagi pembeli domba diharapkan juga mengetahui ciri-ciri fisik domba yang sehat dan bebas dari penyakit. 


\section{Metode Penelitian}

Metode yang digunakan dalam penelitian ini mengacu pada proses pembangunan aplikasi system pakar yang umum, yaitu dengan menggunakan metodologi Expert System Development Life Cycle yang memiliki enam tahap siklus pengembangan. Penekanan dilakukan pada proses identifikasi masalah dan analisis perancangan serta pengujian aplikasi. Pemenuhan konsep system pakar dengan basis pengetahuan dilakukan dengan pengumpulan data dan informasi terkait jenis penyakit domba, dengan studi pustaka dan konsuktasi dengan dokter hewan. Basis data dilakukan dengan analisis dan perancangan menggunakan model diagram konteks, use case diagaram dan flowchart. Adapun konsep inference engine dilakukan dengan penggunaan production rule(if-then) mekanismenya melalui fordward chaining serta penilaian bobot menggunakan model Certainty Factors(CFs). Adapun konsep user interface dan dialog dikembangkan dengan pembuatan antarmuka yang user friendly bagi kemudahan dalam pengisian data dan fakta. Keluaran yang disajikan berupa informasi nilai kepercayaan jenis penyakit yang diagnosis menyerang, sedangkan uji validitas hasil diagnosis dikoparasi dengan pakar(dokter hewan). Selain itu, pengembangan dan pembangunan aplikasi digunakan PHP dan MySQL sebagai tools language dalam kontruksinya.

\subsection{Penyakit Domba}

Penyakit yang menyerang pada domba antara lain adalah Radang pusar, Diare, Cacar mulut, Titani, Radang Limoah, Mulut \& kuku, Ngorok, Kembung, Kudis, Dermatitis, dan Kelenjar susu. Tabel 1 menampilkan jenis penyakit pada doma beserta gejala penyakitnya

Tabel 1. Penyakit dan gejala

\begin{tabular}{|c|l|}
\hline \multicolumn{2}{|c|}{ Tabel 1. Penyakit dan gejala } \\
\hline \multirow{3}{*}{$\begin{array}{c}\text { Radang } \\
\text { Pusar }\end{array}$} & Gejala \\
\cline { 2 - 2 } & Pembengkakan di sekitar pusar \\
\cline { 2 - 2 } Diare & Sakit pada pusar \\
\cline { 2 - 2 } & Dehidrasi \\
\cline { 2 - 2 } & Kotoran encer \\
\hline \multirow{2}{*}{$\begin{array}{l}\text { Cacar } \\
\text { Mulut }\end{array}$} & Gubuh lemah \\
\cline { 2 - 2 } & Mulut melepuh \\
\cline { 2 - 2 } Tetani & Mulut menganga \\
\cline { 2 - 2 } & Kelisah \\
\cline { 2 - 2 } & Kejang otot \\
\hline \multirow{2}{*}{$\begin{array}{c}\text { Radang } \\
\text { Limpa }\end{array}$} & Lubang hidung \& dubur keluar darah \\
\cline { 2 - 2 } & Suhu tubuh meninggi \\
\cline { 2 - 2 } & Suka buang air \\
\hline
\end{tabular}

\begin{tabular}{|c|c|}
\hline \multirow{4}{*}{$\begin{array}{c}\text { Mulut \& } \\
\text { Kuku }\end{array}$} & $\begin{array}{l}\text { Bengkak pada kuku, mulut \& alat } \\
\text { genital }\end{array}$ \\
\hline & Mulut melepuh \\
\hline & Mulut berlendir \\
\hline & Pincang \\
\hline \multirow{4}{*}{ Ngorok } & Kurus \\
\hline & Nafsu makan menurun \\
\hline & Suara mendengkur \\
\hline & Suhu tubuh meninggi \\
\hline \multirow{4}{*}{ Kembung } & Gelisah \\
\hline & Lambung membesar \\
\hline & Nafsu makan menurun \\
\hline & Sesak nafas \\
\hline \multirow{4}{*}{ Kudis } & Gatal di kulit dan badan \\
\hline & Gelisah \\
\hline & Nafsu makan menurun \\
\hline & Senang menggaruk tubuh \\
\hline \multirow{3}{*}{ Dermatis } & Gelisah \\
\hline & Luka bulat dikulit badan \& leher \\
\hline & Senang menggaruk tubuh \\
\hline \multirow{4}{*}{$\begin{array}{l}\text { Kelenjar } \\
\text { Susu }\end{array}$} & Nafsu makan menurun \\
\hline & Putting domba bengkak \\
\hline & Produksi air susu induk berkurang \\
\hline & Senang menggaruk tubuh \\
\hline
\end{tabular}

\subsection{Certainty Factor (Faktor Kepastian)}

Menurut Giarratano dan Riley dalam Latumakulita (2012), sistem pakar harus mampu bekerja dalam ketidakpastian. Sejumlah teori telah ditemukan untuk menyelesaikan ketidakpastian, antara lain Probabilitas klasik (classical probability), Probabilitas Bayes (Bayesian probability), Teori Hartley berdasarkan himpunan klasik (Hartley theory based on classical sets), Teori Shannon berdasarkan pada probabilitas (Shanon theory based on probability), Teori Dempster-Shafer (Dempster-Shafer theory), Teori fuzzy Zadeh (Zadeh's fuzzy theory), dan Faktor kepastian (certainty factor).

Teori Certainty Factor (CF) diusulkan oleh Shortliffe dan Buchanan pada 1975 untuk mengakomodasi ketidakpastian pemikiran (inexact reasoning) seorang pakar. Menurut Turban dalam Syatibi (2012), Certainty Factor merupakan suatu metode yang digunakan untuk menyatakan kepercayaan dalam sebuah kejadian (fakta atau hipotesis) berdasarkan bukti atau penilaian pakar. Certainty Factor (CF) dapat terjadi dengan berbagai kondisi. Diantara kondisi yang terjadi adalah terdapat beberapa antensenden (dalam rule yang berbeda) dengan satu konsekuen yang sama.

Adapun notasi atau rumusan dasar dari Certainty Factor, sebagai berikut :

- Metode 'Net Belief' yang diusulkan oleh Shotliffe dan Buchanan yaitu : 
$\mathrm{CF}($ Rule $)=\mathrm{MB}(\mathrm{H}, \mathrm{E})-\mathrm{MD}(\mathrm{H}, \mathrm{E})$
$\mathrm{MB}(\mathrm{H}, \mathrm{E})=\left\{\frac{\max [p(H \mid E), P(H)]-P(H)}{\max (1,0)-P(H)}\right.$ (2)

$\mathrm{P}(\mathrm{H}) \quad=1$

lainnya

$\operatorname{MD}(\mathrm{H}, \mathrm{E})=\left\{\frac{\min [p(H \mid E), P(H)]-P(H)}{\min (1,0)-P(H)}\right.$

$\mathrm{P}(\mathrm{H}) \quad=1$

Dimana :

$\mathrm{CF}($ Rule $)=$ Faktor kepastian

$\mathrm{MB}(\mathrm{H}, \mathrm{E}) \quad=$ Measure of belief (ukuran kepercayaan) terhadap hipotesis $\mathrm{H}$, jika diberikan evidence $\mathrm{E}$ (antara 0 dan 1$)$

$\mathrm{MD}(\mathrm{H}, \mathrm{E}) \quad=$ Measure of disbelief (ukuran ketidakpercayaan) terhadap evidence $\mathrm{H}$, jika diberikan evidence E (antara 0 dan 1)

$\mathrm{P}(\mathrm{H}) \quad=$ Probabilitas kebenaran hipotesis $\mathrm{H}$

$\mathrm{P}(\mathrm{H} \mid \mathrm{E}) \quad$ = Probabilitas bahwa $\mathrm{H}$ benar karena fakta $\mathrm{E}$

\section{Hasil Dan Pembahasan}

Pada halaman konsultasi terdapat beberapa pertanyaan yang memiliki pilihan jawaban 1 pasti dan 0 tidak pasti.

Proses perhitungan prosentase kepastian penyakit diawali dengan menghitung $\mathrm{CF}$ evidence tunggal dengan menggunakan rumus:

CFtunggal $=$ CFuser $*$ CFpakar

Setelah nilai $\mathrm{Cf}$ masing-masing aturan diperoleh maka nilai $\mathrm{CF}$ tersebut dikombinasikan.

Langkah pertama memilih gejala beserta nilai kepercayaannya. Adapun gejala yang dipilih beserta nilai CF yang dimasukkan sebagai berikut :

- Bengkak pada kuku, mulut \& alat genital (A), CFuser (A)

- Gelisah (B), CFuser (B)

- Kejang otot (C), CFuser (C)

- Lambung membesar (D), CFuser (D)

- Mulut melepuh (E), CFuser (E)

Dari gejala yang telah dipilih muncul rules dari gejala-gejala tersebut, yaitu :

\section{- Rule 1}

IF Gelisah (B)

AND Kejang otot (C)
THEN Tetani

- Rule 4

(A)

IF Bengkak pada kuku, mulut \& alat genital

AND Mulut melepuh (E)

THEN Mulut \& Kuku

- $\quad$ Rule 5

IF Gelisah (B)

AND Lambung membesar (D)

THEN Kembung

Setelah diketahui rules yang muncul, menentukan nilai $\mathrm{CF}$ pakar dari masing-masing gejala sebagai berikut :

Tabel 2. CF Pakar

\begin{tabular}{|l|l|l|l|}
\hline & Rule1 & Rule2 & Rule3 \\
\hline A & &, 8 & \\
\hline B & 0,4 & &, 4 \\
\hline C & & & \\
\hline D & & & 0,6 \\
\hline E & & & \\
\hline
\end{tabular}

Dari rules diatas, rule yang memiliki gejala majemuk dipecah sehingga rule memiliki gejala tunggal. Rule yang dipecah yaitu rule 1 , rule 2 , rule 3 .

\section{Rule 1.1}

IF Gelisah (B)

THEN Tetani

\section{Rule 1.2}

IF Kejang otot (C)

THEN Tetani

\section{Rule 2.1}

IF Bengkak pada kuku, mulut \& alat genital (A)

THEN Mulut \& Kuku

Rule 2.2

IF Mulut melepuh (E)

THEN Mulut \& Kuku

\section{Rule 3.1}

IF Gelisah (B)

THEN Kembung

\section{Rule 3.2}

IF Lambung membesar (D)

THEN Kembung

Setelah rule tunggal terbentuk lalu menghitung nilai kepercayaan. Perhitungan dimulai dengan menghitung $\mathrm{CF}_{\text {pakar }}$ dengan $\mathrm{CF}_{\text {user }}$ dengan 
menggunakan persamaan : $\mathrm{CF}(\mathrm{H}, \mathrm{E})=\mathrm{CF}_{\mathrm{user}} *$ $\mathrm{CF}_{\text {pakar }}$ menjadi :

$$
\begin{array}{ll}
\text { CF 1.1 } & =(\mathrm{B}) *(\mathrm{~B})(\mathrm{R} 1)=0,4 * 1=0,4 \\
\text { CF 1.2 } & =(\mathrm{C}) *(\mathrm{C})(\mathrm{R} 1)=0,6 * 1=0,6 \\
\text { CF 2.1 } & =(\mathrm{A}) *(\mathrm{~A})(\mathrm{R} 2)=0,8 * 1=0,8 \\
\text { CF 2.2 } & =(\mathrm{E}) *(\mathrm{E})(\mathrm{R} 2)=0,6 * 1=0,6 \\
\text { CF 3.1 } & =(\mathrm{B}) *(\mathrm{~B})(\mathrm{R} 3)=0,4 * 1=0,4 \\
\text { CF 3.2 } & =(\mathrm{D}) *(\mathrm{D})(\mathrm{R} 3)=0,6 * 1=0,6
\end{array}
$$

Setelah itu mengkombinasikan $\mathrm{CF}$ tersebut kedalam CF kombinasi dengan rumus: $\mathrm{CF}_{\text {kombinasi }}=$ $\mathrm{CF}(\mathrm{R} 1)+\mathrm{CF}(\mathrm{R} 2)-[\mathrm{CF}(\mathrm{R} 1) * \mathrm{CF}(\mathrm{R} 2)]$. Perhitungan $\mathrm{CF}$ kombinasi setiap penyakit adalah sebagai berikut:

$\mathrm{CF}_{\text {kombinasi }}(\mathrm{CF} 1.1, \mathrm{CF} 1.2)=0,4+0,6-(0,4 * 0,6)$ $=0,76$

$\mathrm{CF}_{\text {kombinasi }}(\mathrm{CF} 2.1, \mathrm{CF} 2.2)=0,8+0,6-(0,8 * 0,6)$ $=0,92$

$\mathrm{CF}_{\text {kombinasi }}(\mathrm{CF} 3.1, \mathrm{CF} 3.2)=0,4+0,6-(0,4 * 0,6)$ $=0,76$

Dari perhitungan diatas, penyakit yang memiliki nilai kepercayaan tertinggi adalah pada rule 4 yaitu penyakit Mulut \& Kuku dengan nilai kepercayaan 0,92.

Pengujian yang dilakukan untuk menguji sistem ini dilakukan dengan pengujian fungsional (black box testing) dan pengujian sistem. Pengujian fungsional dilakukan dengan mempelajari input dan output yang berkaitan. Pengujian sistem adalah proses dimana data yang telah diujikan pada pengujian manual diaplikasikan ke sistem.

\subsection{Pengujian Fungsional}

Pengujian fungsional merupakan tahapan dimana data-data yang ada dimasukkan untuk dilakukan uji coba bersamaan komponen sistem lain untuk mengetahui bahwa komponen sistem sudah berfungsi sesuai yang diharapkan dan sehingga berjalan secara fungsional. Pengujian fungsional dilakukan untuk mengetahui hasil validasi sistem berdasarkan hasil uji coba sistem. Adapun pengujian sistem pada validasi sistem akan

\begin{tabular}{|c|c|c|}
\hline Pengujian & $\begin{array}{c}\text { Hasil yang } \\
\text { diharapkan }\end{array}$ & $\begin{array}{c}\text { Hasil } \\
\text { Pengujian }\end{array}$ \\
\hline $\begin{array}{l}\text { Tambah data } \\
\text { gejala penyakit } \\
\text { dengan form diisi }\end{array}$ & $\begin{array}{l}\text { Kembali ke } \\
\text { interface data } \\
\text { gejala }\end{array}$ & Sesuai \\
\hline $\begin{array}{lr}\text { Tambah data } \\
\text { penyakit dengan } \\
\text { form diisi }\end{array}$ & $\begin{array}{l}\text { Kembali ke } \\
\text { interface data } \\
\text { penyakit }\end{array}$ & Sesuai \\
\hline $\begin{array}{l}\text { Tambah data } \\
\text { pengetahuan } \\
\text { dengan form diisi }\end{array}$ & $\begin{array}{l}\text { Kembali ke } \\
\text { interface data } \\
\text { pengetahuan }\end{array}$ & Sesuai \\
\hline
\end{tabular}
dijelaskan pada tabel 6.1.

Tabel 3. Pengujian Fungsional

\begin{tabular}{|l|l|l|}
\hline \multicolumn{2}{|c|}{ a. Pengujian halaman end-user } \\
\hline \multicolumn{1}{|c|}{ Pengujian } & $\begin{array}{c}\text { Hasil yang } \\
\text { diharapkan }\end{array}$ & $\begin{array}{c}\text { Hasil } \\
\text { Pengujian }\end{array}$ \\
\hline $\begin{array}{l}\text { Interface } \\
\text { halaman utama }\end{array}$ & $\begin{array}{l}\text { Interface } \\
\text { halaman } \\
\text { terdapat menu } \\
\text { beranda, menu } \\
\text { konsultasi, } \\
\text { dan login } \\
\text { untuk pakar } \\
\text { atau admin }\end{array}$ \\
\hline
\end{tabular}

\begin{tabular}{|c|l|l|}
\hline b. Pengujian halaman konsultasi \\
\hline Pengujian & $\begin{array}{l}\text { Hasil yang } \\
\text { diharapkan }\end{array}$ & $\begin{array}{c}\text { Hasil } \\
\text { Pengujian }\end{array}$ \\
\hline $\begin{array}{l}\text { Pengisian form } \\
\text { pada halaman } \\
\text { konsultasi }\end{array}$ & $\begin{array}{l}\text { Muncul } \\
\text { interface hasil } \\
\text { diagnosa }\end{array}$ & Sesuai \\
\hline
\end{tabular}

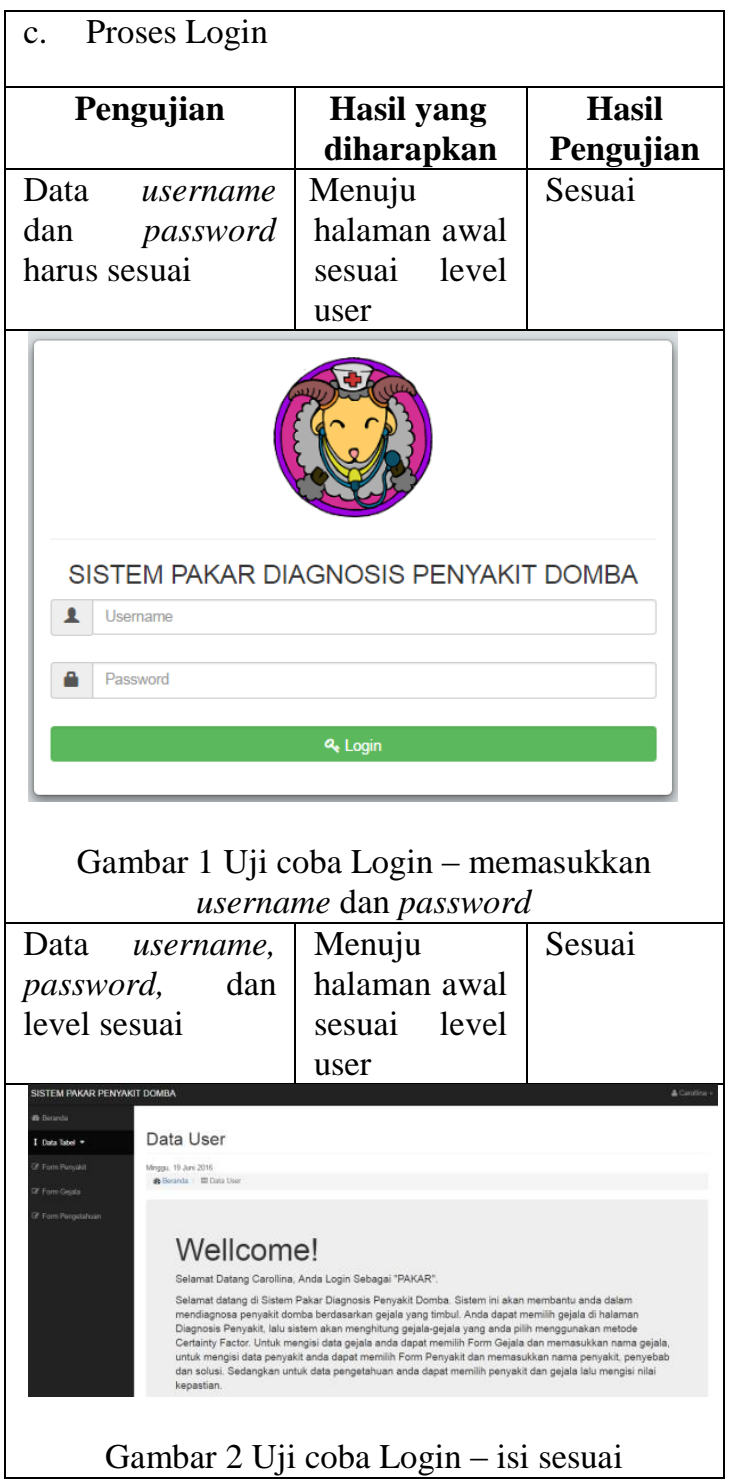




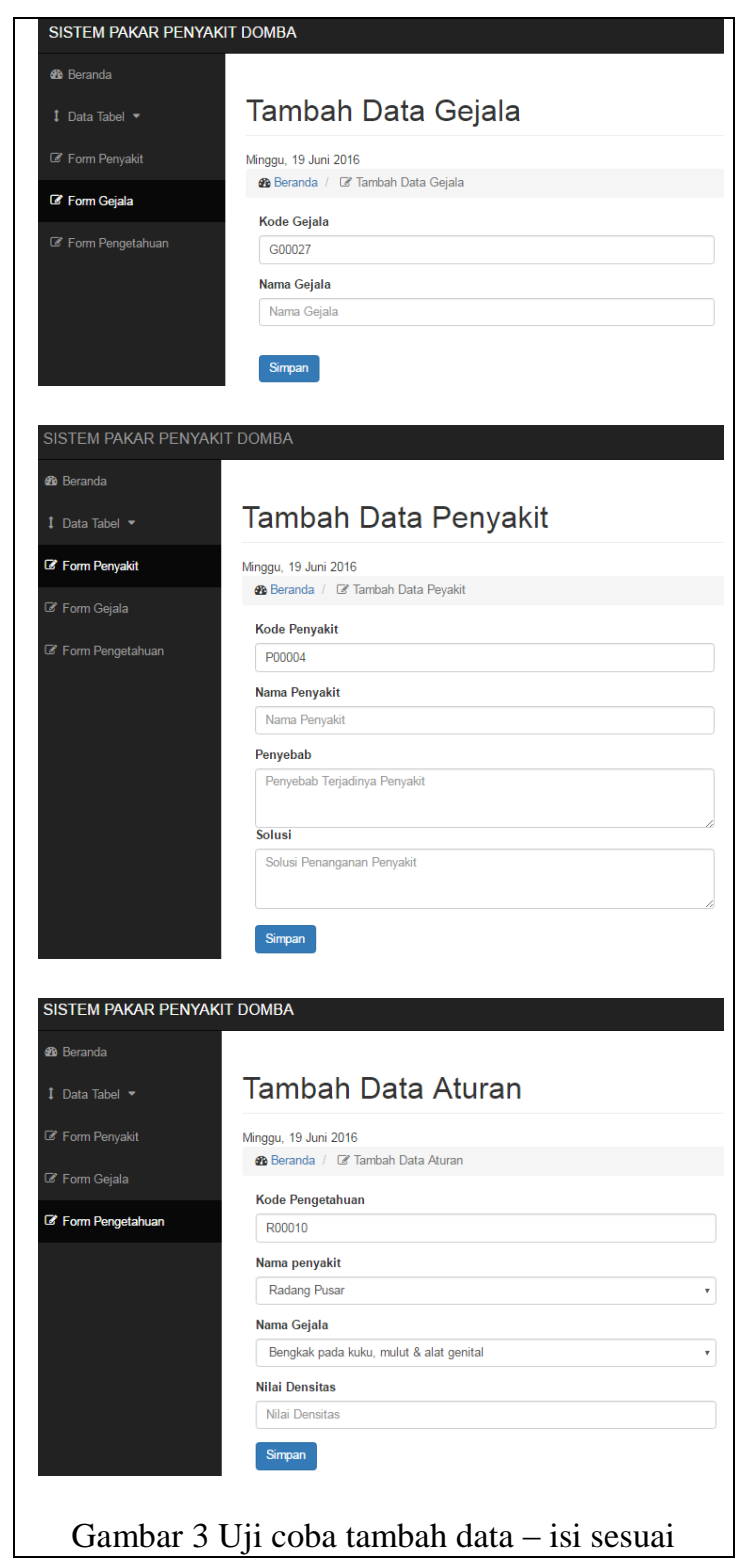

\begin{tabular}{|c|c|c|}
\hline \multicolumn{3}{|c|}{ e. $\quad$ Proses Edit Data } \\
\hline Pengujian & $\begin{array}{l}\text { Hasil yang } \\
\text { diharapkan }\end{array}$ & $\begin{array}{c}\text { Hasil } \\
\text { Pengujian }\end{array}$ \\
\hline $\begin{array}{l}\text { Edit data gejala } \\
\text { penyakit }\end{array}$ & $\begin{array}{l}\text { Kembali ke } \\
\text { interface data } \\
\text { gejala }\end{array}$ & Sesuai \\
\hline $\begin{array}{l}\text { Edit data } \\
\text { penyakit }\end{array}$ & $\begin{array}{l}\text { Kembali ke } \\
\text { interface data } \\
\text { penyakit }\end{array}$ & Sesuai \\
\hline $\begin{array}{l}\text { Edit data } \\
\text { pengetahuan }\end{array}$ & $\begin{array}{l}\text { Kembali ke } \\
\text { interface data } \\
\text { pengetahuan }\end{array}$ & Sesuai \\
\hline \multicolumn{3}{|c|}{$\begin{array}{c}\text { Gambar } 4 \text { Uji coba edit data - data sebelum } \\
\text { diedit }\end{array}$} \\
\hline
\end{tabular}

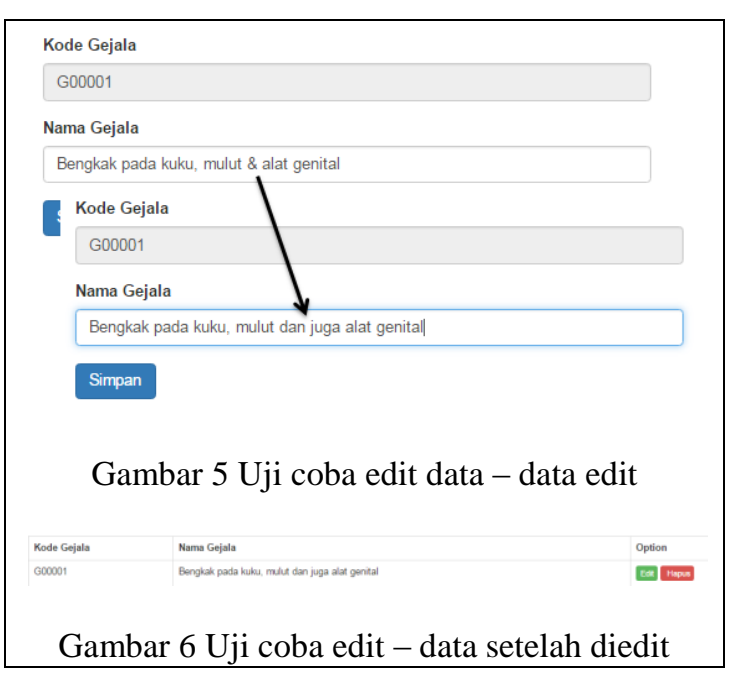

\begin{tabular}{|c|l|c|}
\hline \multicolumn{2}{|c|}{ Proses Hapus Data } \\
\hline Pengujian & $\begin{array}{l}\text { Hasil yang } \\
\text { diharapkan }\end{array}$ & $\begin{array}{c}\text { Hasil } \\
\text { Pengujian }\end{array}$ \\
\hline $\begin{array}{l}\text { Hapus data } \\
\text { gejala penyakit }\end{array}$ & $\begin{array}{l}\text { Kembali ke } \\
\text { interface data } \\
\text { gejala dan } \\
\text { gejala yang } \\
\text { dihapus akan } \\
\text { hilang }\end{array}$ & Sesuai \\
\hline $\begin{array}{l}\text { Hapus data } \\
\text { penyakit }\end{array}$ & $\begin{array}{l}\text { Kembali ke } \\
\text { interface data } \\
\text { penyakit dan } \\
\text { penyakit yang } \\
\text { dihapus akan } \\
\text { hilang }\end{array}$ & Sesuai \\
\hline $\begin{array}{l}\text { Hapus data } \\
\text { pengetahuan }\end{array}$ & $\begin{array}{l}\text { Kembali ke } \\
\text { interface data } \\
\text { pengetahuan } \\
\text { dan } \\
\text { pengetahuan } \\
\text { yang dihapus } \\
\text { akan hilang }\end{array}$ & Sesuai \\
\hline
\end{tabular}

\begin{tabular}{|l|l|l|}
\hline \multicolumn{2}{|l|}{ g. Proses logout } \\
\hline Pengujian & $\begin{array}{l}\text { Hasil yang } \\
\text { diharapkan }\end{array}$ & $\begin{array}{l}\text { Hasil } \\
\text { Pengujian }\end{array}$ \\
\hline $\begin{array}{l}\text { Melakukan } \\
\text { Logout }\end{array}$ & $\begin{array}{l}\text { Kembali ke } \\
\text { halaman login }\end{array}$ & Sesuai \\
\hline
\end{tabular}




\section{Kesimpulan dan Saran}

Dari hasil perancangan dan pembuatan sampai dengan pengujian program system pakar diagnosis penyakit pada domba, maka dapat diperoleh simpulan dan saran untuk pengembangan program lebih lanjut, yaitu sebagai berikut :

\subsection{Kesimpulan}

Pada penelitian ini menghasilkan beberapa kesimpulan yaitu antara lain :

Penerapan metode Certainty Factor (CF) menggunakan basis pengetahuan (knowledge base) dan mesin inferensi dapat digunakan untuk membangun suatu system pakar berbasis web untuk dignosa penyakit pada domba berdasarkan pada beberapa fakta dan gejala.

Sistem pakar yang dibangun dapat mengenali dan mengetahui penyakit pada domba menggunakan metode certainty factor (CF) dan menghasilkan solusi untuk membantu penanganan pada penyakit.

Nilai kepercayaan yang dihasilkan dari system ini sama dengan hasil perhitungan secara manual dengan menggunakan teori Certainty Factor. Sehingga keakuratan hasilnya sudah sesuai dengan perhitungan yang diharapkan.

Dari hasil pengujian pada penelitian ini didapatkan nilai keakuratan sebesar 73,3\%.

\subsection{Saran}

Pada penelitian ini ada beberapa saran yang dapat diberikan, meliputi :

Perlu dipertimbangkan untuk membuat penyajian pilihan data gejala yang lebih baik agar lebih mudah dalam penggunaan system pakar ini.

Data pada system seharusnya selalu di-update oleh admin secara berkala sesuai dengan perkembangan yang berkaitan dengan sistem.

\section{Daftar Pustaka:}

Bambang, S \& Sudarmono, A., (2011): Beternak Domba. Jakarta: Penebar Swadaya.

Daniel, \& Virginia, G., (2010): Implementasi Sistem Pakar Untuk Mendiagnosis Penyakit Dengan Gejala Demam Menggunakan Metode Certainty Factor, Jurnal Informatika, Volume 6 Nomor 1, April 2010, Teknik Informatika, Universitas Kristen Duta Wacana.

Gandika, S., Dwi, I. K., (2014): Sistem Pakar Diagnosa Awal Penyakit Kulit Pada Sapi Bali dengan Menggunakan Metode Forward Chaining dan Certainty Factor, Jurnal Nasional Pendidikan Teknik Informatika ISSN 2089673, STMIK STIKOM Indonesia Denpasar.
Kasmuni. (2011): Sistem Pakar Identifikasi Bentuk Keris Jawa Dengan Metode Certainty Factor, Universitas Islam Negeri Syarif Hidayatullah, Jakarta

Latumakulita, L. A., (2013): Sistem Pakar Pendiagnosa Penyakit Anak Menggunakan Certaity Factor (CF), Jurnal Ilmiah Sains Vol. 12 No. 2.

Nigroho, B., (2010): Membuat Aplikasi Sistem Pakar Dengan PHP Dan Editor Dreamweaver, Gava Media, Yogyakarta.

Nuraisyah, S., (2014): Sistem Pakar Untuk Mendiagnosis Penyakit Kusta Menggunakan Metode Backward Chaining, Skripsi Mahasiswa D4 Teknik Informatika Politeknik Negeri Malang

Sutojo, T., (2011): Kecerdasan Buatan, Semarang: Andi, Yogyakarta 